\title{
A site-based model for professional development in mathematics at the elementary school level
}

\author{
Denise S. Mewborn \\ University of Georgia \\ email: dmewborn@coe.uga.edu \\ Patricia D. Huberty \\ University of Georgia \\ email: pattihuberty@charter.net
}

Teaching is a profession in which one must continue to learn because there is no one right way to teach, and one does not "master" teaching. Students change, curricula change, and schools change; thus there is always a need to grow as teachers. Heaton (1994, 2000), an experienced teacher who engaged in a yearlong self-study as she tried to change her teaching practice to be consistent with current calls for reform, characterized teaching as "inherently under construction ... and continuous invention” (p. 341). She noted that teaching is very situation-specific so teachers must constantly tinker with their practice. Cobb, Wood and Yackel (1990) asserted that a teacher's classroom is a "learning laboratory" (p. 131). In response to requests from local teachers, we developed a professional development model based on the notions of a classroom as a learning laboratory and teachers as learners. Our overarching goal was to help teachers reconsider the fundamentals of both what it means for children to learn mathematics, and for them to teach mathematics. Our sub-goal was to improve student achievement in mathematics by enhancing teachers' classroom practices to enable them to meet the learning needs of all students.

In this paper we present a description and evaluation of a model of professional development that we have been using with elementary school mathematics teachers for several years. We describe the origin of the model and its connections to both teachers' needs and the literature-base on teacher development, the implementation of the model, and the results we have seen in both student achievement and teachers' practices.

The professional development projects described in this manuscript were supported by funding from the Eisenhower Program for Improving Mathematics and Science Instruction and the Teacher Quality Grants Program.

\section{Conceptual Basis for the Model}

Our work in professional development was born out of needs identified by teachers and administrators in local schools. Concerned about overall student achievement and disparities in teachers' comfort levels with and support for teaching mathematics versus teaching literacy, the leadership team from an elementary school approached us and asked how we might help them address their concerns. As we collaborated on the design of the professional development project, teachers brought to the table their prior experiences with professional development and their understanding of the needs facing their students and fellow teachers. We brought to the table our past experiences with professional development and our knowledge of the research literature on effective practices in professional development. Together, we crafted a workable model that has since been implemented in five schools.

The teachers' prior experiences with professional development suggested three major themes. First, mathematics staff development that spans grades prekindergarten through fifth grade is too general to be useful. The content demands and student needs in place value, geometry, data analysis and other topics are very different across the grades spanned in an elementary school. Second, staff development must be directly linked to teachers' classroom practices. Teachers told us they did not want to attend a oneweek "crash course" in the summer or an after school workshop that resulted in a notebook of activities that they would have to sift through in order to find what applied in their classrooms. They wanted sustained staff development. Third, the teachers wanted the staff development activities to be site-based so that the staff 


\section{Denise Mewborn, Patricia Huberty}

developers understood their students, their curriculum, and their school structures.

Although the research base on effective professional development is in its infancy, the teachers' concerns resonated with common messages in the literature. These messages include the importance of focusing on mathematics content, student thinking, and curriculum (Gearhart et al., 1999), situating staff development in the context of teachers' practices (Fennema et al., 1996, Kazemi \& Franke, 2000; Schifter, 1998), providing sustained staff development (Garet, Porter, Desimone, Birman, \& Yoon, 2001; Schifter, 1998), and fostering collegial relationships through staff development (Garet et al., 2001; Silver, Smith, \& Nelson, 1995; Stein, Silver, \& Smith, 1998).

\section{Description of the Model}

Our professional development model has three main components. The first and most important is classroom-based support for individual teachers and/or teams of teachers. The second is quarterly cross-gradelevel staff development sessions, and the third is monthly grade-level meetings. Two additional components of the project include support for the school's math committee and support for parent involvement in students' mathematics learning. This manuscript describes only the classroom-based support aspect of the project.

\section{Staff}

The project staff consists of a university-based mathematics educator (first author), a school-based mathematics specialist (second author), and a university-based mathematician. The mathematics educator serves as the project coordinator to mediate university and school paperwork and politics. The mathematics educator also serves as a resource and support for the mathematics specialist. The schoolbased mathematics specialist is an experienced classroom teacher with a strong background in mathematics and mathematics education. The specialist is responsible for the bulk of the professional development activities described in this manuscript. The university-based mathematician is a person with an interest in school mathematics who serves as a sounding board when mathematical issues arise. Across the five schools in which this model of professional development has been employed, there have been two different mathematics educators, three different mathematics specialists, and three different mathematicians.

\section{Contexts}

The five schools in which we have implemented the model are in the same school district in the town where our university is located. The elementary schools are Pre-K or $\mathrm{K}$ through $5^{\text {th }}$ grade schools (ages 4 through 11). The district contains 13 elementary schools and serves over 11,000 students in elementary, middle and high school, with $62 \%$ of these students living in poverty as defined by the federal government ${ }^{1}$. The demographics of individual schools vary widely, however. The demographics of the five schools in which we have employed this professional development model are summarized in Table 1.

\section{Implementation.}

The focus of the classroom-based support is to prepare teachers to effectively use strategies known to enhance student achievement: hands-on learning, group work, class discussions, and the use of questions requiring higher-order thinking in both instruction and assessment (Milken Family Foundation, 2000). The support occurs primarily in the form of planningteaching-debriefing cycles with individual teachers or teams of teachers at the same grade level. The goal of working with a team of teachers is to promote a "community of learners" among the staff so that mathematics teaching becomes a publicly shared responsibility (Garet et al., 2001). A typical planningteaching-debriefing cycle with one grade level includes one or two planning periods in which teachers and the mathematics specialist discuss the upcoming sequence of lessons. This discussion includes an assessment of students' readiness for the topic (including a discussion of common misconceptions students have and known weaknesses in students' achievement in this area), a review of the topics that have already been covered and in what manner, a summary of teachers' goals for these lessons, and an exploration of possible manipulatives, representations, and examples to be used in the lessons. Between planning sessions the mathematics specialist and the teachers spend time doing individual

1 Students are identified as living in poverty by a federal standard based on household income. Students living in poverty are eligible to receive a hot meal at lunch at a reduced price or for free, depending on their family's income. This is commonly referred to as the "free and reduced price lunch rate" in the United States and is synonymous with the poverty rate. 


\section{Professional development in mathematics at the elementary school level}

planning and gathering resources. During the next planning session they share their plans and resources with the team to gather suggestions for modification.

Then, the lessons are implemented. The implementation occurs in a variety of ways-with each teacher teaching the lessons in her own classroom with of the model because it enables teachers to see individual students through new eyes. This model promotes active learning on the part of teachers (Garet et al., 2001) because they are "actively engaged in meaningful discussion, planning, and practice" (Garet et al., 2001, p. 925).

\begin{tabular}{|l|c|c|c|c|c|}
\hline & School A & School B & School C & School D & School E \\
\hline Number of students in K-5 & 430 & 400 & 525 & 400 & 430 \\
\hline \% of students living in poverty & $82 \%$ & $47 \%$ & $56 \%$ & $67 \%$ & $81 \%$ \\
\hline Race/ethnicity of students: & 15 & 42 & 33 & 28 & 12 \\
$\quad$ White & 55 & 36 & 58 & 55 & 75 \\
$\quad$ Black & 25 & 7 & 2 & 12 & 9 \\
$\quad$ Hispanic & 2 & 24 & 4 & 2 & 2 \\
$\quad$ Asian & 5 & 4 & 4 & 3 & 2 \\
$\quad$ Multi-racial & & & & & \\
\% of 4 grade students who failed to meet $_{\text {mathematics standards on criterion- }}$ & $49 \%$ & $24 \%$ & $45 \%$ & $38 \%$ & $68 \%$ \\
referenced test in 2000-2001 & & & & & \\
\hline
\end{tabular}

Table 1: School Demographics

support from the mathematics specialist, with one teacher teaching the lessons with support from the mathematics specialist as other teachers observe, with the mathematics specialist teaching some lessons and teachers conducting others. The goal is for teachers to do as much of the teaching as possible with the mathematics specialist and other teachers serving in supporting roles to increase the teachers' pedagogical skills and comfort so that they are able to continue this type of instruction when the project is finished. In practice, however, we find that during the first year of the project teachers are more comfortable with the specialist doing most of the teaching. Several times during the instructional sequence the mathematics specialist and the teachers hold debriefing sessions to discuss evidence of students' mathematical thinking, how the instruction facilitated student learning, the appropriateness of the materials being used, and the possible next steps after these lessons. There is an emphasis on examining student work during these sessions. The mathematics specialist leads discussions of students' verbal comments, questions, and explanations and promotes examination of students' written work (produced during the lesson or as homework). This focus on students' thinking is intended to draw teachers' attention to the learning of all students and to help them focus on instructional strategies that are meaningful for their students. We have found that this is a particularly powerful aspect

\section{Impact of the Model}

Across the five schools we have seen a variety of changes in teachers' classroom practices in mathematics. For some teachers this change is in one particular content area, such as fractions, in which they now feel more confident about teaching the material because they understand it themselves. Other teachers feel better about motivating students to learn mathematics through the use of children's literature, manipulatives and group work. Others have changed their approach to classroom discourse because they have seen the benefits of having students talk and listen to one another about mathematics. Some teachers have found a connection between their longheld views about teaching and learning in other subjects (such as literacy or social studies) and their emerging views about mathematics. In schools where administrators have been actively involved in observing instruction throughout the project, we have seen a change in their expectations. Many administrators have gained an appreciation for the ways that mathematics instruction might be conducted and for the value of discourse in the classroom.

In one school, the professional development process facilitated a school-wide examination of the practice of ability grouping students for mathematics instruction. Teachers in the fourth and fifth grades in this school believed that students needed to be 


\section{Denise Mewborn, Patricia Huberty}

grouped with same-ability peers so that mathematics instruction could be provided on an appropriate level. In general, this arrangement led to a predominant focus on lower-level skills with the lowest-achieving students and an accelerated pace with a modicum of problem solving with the highest-achieving group of students. When the mathematics specialist encouraged the fourth-grade teachers to engage their students in more problem solving tasks, the teachers expressed considerable skepticism that their lowest-achieving students were capable of problem solving. The mathematics specialist therefore spent a week in each classroom and presented the same four problem

\begin{tabular}{|l|l|l|l|l|}
\hline School & $\mathbf{2 0 0 0}$ & $\mathbf{2 0 0 1}$ & $\mathbf{2 0 0 2}$ & $\mathbf{2 0 0 3}$ \\
\hline School A & $51 \%$ & $52 \%$ & $56 \%$ & $61 \%$ \\
\hline School B & $81 \%$ & $76 \%$ & $68 \%$ & $73 \%$ \\
\hline School C & $73 \%$ & $55 \%$ & $66 \%$ & $72 \%$ \\
\hline School D & $59 \%$ & $62 \%$ & $46 \%$ & $65 \%$ \\
\hline School E & $50 \%$ & $33 \%$ & $24 \%$ & $58 \%$ \\
\hline
\end{tabular}

Table 2: Test scores for participating schools

solving tasks to each group. All three teachers participated in each lesson, working with small groups of students while the mathematics specialist led the lesson. Students in all three groups successfully solved the problems using a variety of strategies. As a result of these lessons and the associated discussions, the teachers began to examine their perceptions of what students could do and the role of problem solving in learning mathematics. They also began to reconsider both the mathematics content and the teaching strategies to which they exposed their students. Over the last two years, the entire school (including parents) has begun a discussion of how to best meet the needs of the academically diverse student body, and ability grouping has come into question. As a result of these discussions, the school has implemented an inclusion model for mathematics instruction in grades $\mathrm{K}, 1$ and 2. Rather than separating children by ability, the teachers who are certified for special education and gifted education go into the general education classroom during mathematics instruction rather than pulling children out of the classroom for specialized instruction. This experiment is ongoing so we do not yet have test data or anecdotal data from parents and teachers. However, we believe that it is a sign of progress that teachers and parents are questioning the value of ability-grouping and are taking steps to understand it better.

Test scores, while they cannot be solely attributed to professional development, provide some evidence of improved student achievement. The data in Table 2 show the percentage of fourth-grade students who met or exceeded standards on a state-mandated criterionreferenced test. We administered a teacher survey in

Please mark the extent to which you agree or disagree with the following statements:

\begin{tabular}{|l|c|c|c|c|}
\hline & Strongly disagree & Disagree & Agree & Strongly agree \\
\hline $\begin{array}{l}\text { The kind of teaching advocated by the project is } \\
\text { helping my students reach higher levels of mathematics } \\
\text { achievement. }\end{array}$ & 1 & 4 & 22 & 17 \\
\hline $\begin{array}{l}\text { The type of mathematics teaching advocated by the } \\
\text { project is very different from what I have been doing. }\end{array}$ & 1 & 15 & 22 & 7 \\
\hline $\begin{array}{l}\text { I value the kind of mathematics teaching advocated by } \\
\text { the project. }\end{array}$ & & 1 & 15 & 28 \\
\hline $\begin{array}{l}\text { The project provided me with knowledge, skills, or } \\
\text { resources that are useful to me in the classroom. }\end{array}$ & & 2 & 17 & 26 \\
\hline $\begin{array}{l}\text { The project helped me pay closer attention to particular } \\
\text { things I was doing in the mathematics classroom. }\end{array}$ & & 3 & 16 & 26 \\
\hline $\begin{array}{l}\text { The project led me to think about an aspect of my } \\
\text { mathematics teaching in a different way. }\end{array}$ & & 1 & 21 & 23 \\
\hline The project led me to try new things in the classroom. & & 1 & 20 & 24 \\
\hline I feel more confident about teaching mathematics now. & & 4 & 27 & 13 \\
\hline
\end{tabular}

Table 3: Teacher survey 
Schools C, D, and E in order to gauge whether professional development was having an impact on teachers beyond supplying them with new mathematical tasks and materials. The survey items in Table 3 were taken from the Teacher Questionnaire developed for the Study of Instructional Improvement conducted by the Consortium for Policy Research in Education at the University of Michigan. We selected items from this existing survey because we thought these items tapped the kinds of deeper teacher learning we were trying to foster. Overall, we believe that our informal and formal assessments of the professional development project show that we are meeting our goals.

\section{Critique of the Professional Development Model}

This staff development model has advantages and disadvantages. We believe the advantages outweigh the disadvantages, but it is important to articulate both. The advantages of the model primarily correspond to the characteristics of effective staff development identified by the teachers and in the literature. All staff development is conducted entirely at the school site and involves all teachers in the building who have responsibility for mathematics instruction, which facilitates school-wide, within grade level, and cross grade level dialogue about mathematics instruction, curriculum, and assessment. By conducting staff development activities in the building where teachers work, we are able to see first-hand their teaching environment and work with their students. Teachers do not have to be away from the building during the school day or drive to another location at the end of a long school day for staff development. Furthermore, they do not have to endure staff development that "won't work with my students" because we do work with their students.

The "grain size" of our approach is both an advantage and a disadvantage. The grain size of most professional development is too large (e.g. geometry for K-5 teachers). Our grain size is one classroom at a time and one topic at a time. Using this approach, we do not "cover" every topic with every teacher. However, we believe that the impact is far greater when we help teachers think differently about the entire enterprise of teaching mathematics via specific lessons on particular topics. By taking this approach, we work to build content knowledge as well as pedagogical content knowledge in the mathematics that teachers teach (Borko and Putnam, 1995) rather than simply focusing on building isolated skill sets (National Commission on Mathematics and Science Teaching, 2000; Renyi, 1996).

A substantial disadvantage of our model is that it requires a significant commitment of resources. The mathematics specialist is essentially an additional teacher in the building, but she does not contribute to reducing the student-teacher ratio. We have been fortunate to have external funding for our work thus far, but any replication or expansion of this model is expensive. In addition, the human resources required for this model are considerable. The mathematics specialist must be someone whose content and pedagogical content knowledge span the mathematics curriculum of pre-kindergarten through fifth grade. In addition, the specialist must be able to work well with teachers as peers in a non-evaluative, coaching relationship. It does not necessarily follow that someone who is a good teacher of mathematics to children is a good professional developer. Thus, it takes a person with fairly specialized knowledge and skills to serve as a mathematics specialist. We do not have structures in which to prepare such people, so it is rather an ad hoc creation.

As with most models of professional development, this one fails to address problems of sustainability. While it is plausible that changes in a particular teacher's practice will be sustained over the long term, this model does not account for teacher turnover at the school level. This model does not necessarily lead to the development of a professional community of learners in the school to support teachers who are new to the school as they develop teaching practices that are consistent with those of the rest of the school.

\section{Conclusion}

As a field of inquiry, mathematics education suffers from a lack of research on professional development and teacher learning. What we have is a collection of "cases" much like the one we have provided here. Most accounts are descriptive, and a few contain some data about effectiveness. We must guard against viewing these accounts as simply a collection of stories. We need to mine these stories by conducting cross-case analyses in order to develop theoretical frameworks about professional development that account for teachers' knowledge, teachers' practice, and student learning. As Cooney (1994) note: "If we are to move beyond collecting interesting stories, theoretical perspectives need to be developed that allow us to see how those stories begin to tell a larger 


\section{Denise Mewborn, Patricia Huberty}

story” (p. 627). The development of theoretical frameworks will help us design future professional development projects, conduct research on professional development, and evaluate the effectiveness of such projects. Thus, it is critically important for mathematics educators to craft professional development programmes that reflect best practices, to share these programmes widely, and to research the effectiveness of such program so that we can move toward effective means for supporting teachers as they engage in the continual journey that is teaching.

\section{References}

BORKO, H., \& PUTNAM, R. T., 1995, “Expanding a teacher's knowledge base: A cognitive psychological perspective on professional development” in T. R. Guskey, (Ed.), Professional development in education: New paradigms and practices: pp. 35-65. New York: Teachers College Press

COBB, P., WOOD, T., \& YACKEL, E., 1990, "Classrooms as learning environments for teachers and researchers" in R. Davis, C. Maher, \& N. Noddings (Eds.), Constructivist views on the teaching and learning of mathematics (JRME Monograph 4, pp. 125-146) Reston, VA: National Council of Teachers of Mathematics

COONEY, T. J., 1994, "Research and teacher education: In search of common ground" in Journal for Research in Mathematics Education, 25(6), pp. 608-636

FENNEMA, E., CARPENTER, T. P., FRANKE, M. L., LEVI, L., JACOBS, V. R., \& EMPSON, S. B., 1996, "A longitudinal study of learning to use children's thinking in mathematics instruction" in Journal for Research in Mathematics Education 27, pp. 403-434

GARET, M.S., PORTER, A.C., DESIMONE, L., BIRMAN, B.F., \& YOON, K.S., 2001, "What makes professional development effective? Results from a national sample of teachers" in American Educational Research Journal, 38(4), pp. 915-945

GEARHART, M., SAXE, G. B., SELTZER, M. SCHLACKMAN, J., CHING, C. C., NASIR, N., FALL, R., BENNETT, T., RHINE, S., \& SLOAN, T. F., 1999, "Opportunities to learn fractions in elementary mathematics classrooms" in Journal for Research in Mathematics Education, 30, pp. 286-315
HEATON, R. M., 2000, Teaching mathematics to the new standards: Relearning the dance. New York: Teachers College Press.

HEATON, R. M., 1994, "Creating and studying a practice of teaching elementary mathematics for understanding” (Doctoral dissertation, Michigan State University, 1994), Dissertation Abstracts International, 55-07A: 1860

KAZEMI, E., \& FRANKE, M. L., 2000, "Understanding teacher learning as changing participation in communities of practice" in M. L. Fernández (Ed.) Proceedings of the TwentySecond Annual Meeting of the North American Chapter of the International Groups for the Psychology of Mathematics Education: pp. 561566, Columbus, OH: ERIC Clearinghouse for Science, Mathematics, and Environmental Education

MILKEN FAMILY FOUNDATION, 2000, How Teaching Matters: Bringing the Classroom Back into Discussions of Teacher Quality, Princeton, NJ: ETS. Available at: www.ets.org/research/pic

NATIONAL COMMISSION ON MATHEMATICS AND SCIENCE TEACHING (NCMST), 2000, Before it's too late: A report to the nation from The National Commission on Mathematics and Science Teaching for the 21st century, Jessup, MD: National Commission on Mathematics and Science Teaching

RENYI, J., 1996, Teachers take charge of their learning: Transforming professional development for student success, Washington, DC: National Foundation for the Improvement of Education

SCHIFTER, D., 1998, "Learning mathematics for teaching: From a teachers' seminar to the classroom." in Journal of Mathematics Teacher Education, 1, pp. 55-87

SILVER, E. A., SMITH, M. S., \& NELSON, B. S., 1995, "The QUASAR Project: Equity concerns meet mathematics education reform in the middle school” in W. G. Secada, E. Fennema, \& L. B. Adajian (Eds.), New directions for equity in mathematics education: pp. 9-56 New York: Cambridge University Press and National Council of Teachers of Mathematics

STEIN, M. K., SILVER, E. A., \& SMITH, M. S., 1998), "Mathematics reform and teacher development from the community of practice perspective" in J. Greeno \& S. Goldman (Eds.), Thinking practices: A symposium on mathematics and science learning: pp. 17-52, Hillsdale, NJ: Erlbaum 